\title{
Lipoprotein (a) and cardiovascular risk factors in children and adolescents
}

\author{
Lipoproteína (a) e fatores de risco cardiovascular em crianças e adolescentes \\ Lipoproteína (a) y factores de riesgo cardiovascular en niños y adolescentes
}

Ástrid Camêlo Palmeira' ${ }^{1}$ Adriana Amorim de F. Leal', Nathaly de Medeiros N. Ramos ${ }^{1}$, José de Alencar F. Neto',

Mônica Oliveira da S. Simões ${ }^{1}$, Carla Campos M. Medeiros ${ }^{1}$

\section{ABSTRACT}

Objective: To review the relationship between lipoprotein (a) $[\mathrm{Lp}(\mathrm{a})]$ and other risk factors for cardiovascular disease (CVD) in children and adolescents.

Data sources: This systematic review included studies from 2001 to 2011, a ten-year time period. Epidemiological studies with children and/or adolescents published in English, Portuguese or Spanish and fully available online were included. The searches were performed in Science Direct, PubMed/Medline, BVS (Biblioteca Virtual em Saúde) and Cochrane Library databases, using the following combination of key-words: "lipoprotein a" and "cardiovascular diseases" and "obesity".

Data synthesis: Overall, 672 studies were obtained but only seven were included. Some studies assessed the family history for CVD. In all of them, Lp(a) levels were increased in patients with family history for CVD. There was also a positive correlation between Lp(a) and LDL-cholesterol, total cholesterol, and apolipoprotein B levels, suggesting an association between $\mathrm{Lp}(\mathrm{a})$ levels and the lipid profile.

Conclusions: The evidence that CVD may originate in childhood and adolescence leads to the need for investigating the risk factors during this period in order to propose earlier and possibly more effective interventions to reduce morbidity and mortality rates.
Key-words: cardiovascular diseases; obesity; child; adolescent; lipoprotein(a).

\section{RESUMO}

Objetivo: Revisar a relação da lipoproteína (a) [Lp(a)] com outros fatores de risco para doenças cardiovasculares (DCV) em crianças e adolescentes.

Fontes de dados: Revisão sistemática, com estudos do período de 2001 a 2011, caracterizando um recorte temporal de dez anos. Incluíram-se estudos epidemiológicos realizados com crianças e/ou adolescentes, publicados em inglês, português ou espanhol, disponíveis integralmente on-line. Realizou-se a busca nas bases de dados Science Direct, PubMed/Medline, Biblioteca Virtual em Saúde e Biblioteca Cochrane, utilizando-se a combinação dos descritores "lipoproteína a" e "doenças cardiovasculares" e "obesidade".

Síntese dos dados: Encontraram-se 672 estudos, porém apenas sete foram incluídos na revisão. Alguns trabalhos avaliaram o histórico familiar para DCV. Em todos, os níveis de $\mathrm{Lp}$ (a) eram aumentados nos pacientes com esse histórico. Observou-se também correlação positiva entre Lp(a) e colesterol LDL, colesterol total e apolipoproteína B, sugerindo uma associação entre concentrações de Lp(a) e perfil lipídico.

Conclusões: A evidência de que as DCV podem ter sua origem na infância e na adolescência leva à necessidade de se
Instituição: Universidade Estadual da Paraíba (UEPB), Campina Grande, PB, Brasil

'UEPB, Campina Grande, PB, Brasil

\author{
Endereço para correspondência: \\ Ástrid Camêlo Palmeira \\ Rua Almeida Barreto, 2.896 \\ CEP 58428-190 - Campina Grande/PB \\ E-mail: astridcp1@hotmail.com \\ Fonte financiadora: Este trabalho é parte da dissertação de mestrado de \\ Ástrid Camêlo Palmeira, financiada pelo PROPESQ e CNPq \\ Conflito de interesse: nada a declarar \\ Recebido em: 21/9/2012 \\ Aprovado em: 4/3/2013
}


investigarem os fatores de risco nesse período, para planejar intervenções cada vez mais precoces e, possivelmente, mais efetivas, reduzindo a morbimortalidade.

Palavras-chave: doenças cardiovasculares; obesidade; criança; adolescente; lipoproteína(a).

\section{RESUMEN}

Objetivo: Revisar la relación de la lipoproteína (a) $\{\mathrm{Lp}(\mathrm{a})\}$ con otros factores de riesgo para enfermedades cardiovasculares (ECV) en niños y adolescentes.

Fuentes de datos: Se trata de una revisión sistemática, realizada de julio a agosto de 2011, con estudios del periodo de 2001 a 2011, caracterizando un recorte temporal de diez años. Se incluyeron estudios epidemiológicos realizados en niños y/o adolescentes, publicados en inglés, portugués o español, disponibles integralmente en línea. Se realizó la búsqueda en las bases de datos Science Direct, PubMed/Medline, Biblioteca Virtual en Salud y Biblioteca Cochrane, utilizándose la combinación de los descriptores «lipoproteína a», «enfermedades cardiovasculares» $\mathrm{y}$ «obesidad».

Síntesis de los datos: Se encontraron 672 estudios, pero solamente siete fueron incluidos en la revisión. Algunos trabajos evaluaron el histórico familiar para ECV. En todos, los niveles de $\mathrm{Lp}$ (a) eran aumentados en los pacientes con ese histórico. Se observó además la correlación positiva entre Lp(a) y colesterol LDL, colesterol total y apolipoproteína B, sugiriendo una asociación entre concentraciones de $\mathrm{Lp}$ (a) y perfil lipídico.

Conclusiones: La evidencia de que las ECV pueden tener su origen en la infancia y adolescencia lleva a la necesidad de investigar los factores de riesgo en ese periodo, para planear intervenciones cada vez más tempranas y, posiblemente, más efectivas, reduciendo la morbimortalidad.

Palabras clave: enfermedades cardiovasculares; obesidad; niño; adolescente; lipoproteína (a).

\section{Introduction}

Cardiovascular diseases (CVD) are characterized as the main cause of death worldwide. These diseases develop slowly and progressively over life since early childhood. Among the variables associated with CVD, excess of weight (overweight and obesity) is one of the most important factors $^{(1)}$. Therefore, it is believed that the prevention of CVD should begin in early childhood, with a special focus on the education process for cardiovascular health promotion, emphasizing the importance of the diet and the regular practice of physical activities over life ${ }^{(2)}$.

Accordingly, new risk markers related to lipid metabolism have been identified and studied, among which lipoprotein (a) or Lp(a) stands out because its persistently high plasma levels appear to be strong and independently associated with atherosclerosis ${ }^{(3,4)}$. Although the mechanisms of action associated with $\mathrm{Lp}(\mathrm{a})$ are still unclear, their involvement in atherosclerotic processes is active and silent ${ }^{(5)}$. Recent studies have reported that $\mathrm{Lp}(\mathrm{a})$ is a stable risk marker of the major forms of vascular diseases, with atherogenic and thrombotic properties ${ }^{(6)}$.

In this context, studies should be carried out to identify the cardiovascular risk factors in this age group and to clearly determine the problem magnitude, guiding actions to combat and prevent these risks. Thus, assuming that $\mathrm{Lp}$ (a) is related to other cardiovascular risk factors, this review summarized the main results of studies performed with this protein and verified its relationship with other risk factors for CVD in children and adolescents.

\section{Method}

To screen the most recent publications on this topic, a systematic and descriptive review was carried out, from July to August, 2011. Studies from 2001 to 2011 were included, featuring a ten-year time period. Epidemiological studies with children and/or adolescents, published in English, Portuguese or Spanish and fully available online were included.

The databases used for screening the articles were Science Direct, PubMed/Medline, Biblioteca Virtual em Saúde (BVS Virtual Library on Health) and Cochrane Library, applying the following key-words combination: "lipoprotein a" and "cardiovascular diseases" and "obesity". The first screening included the combination of listed key-words in order to identify abstracts in duplicate, and to exclude references related to abstracts without full article available, books and book indexes, review articles and those not specifically related to the topic. The considered articles were fully read, excluding those focusing on other outcomes. A new stage of research was conducted, in which the references of eligible articles were reviewed to capture manuscripts not found in the first search. 
Table 1 - Characteristics and main results of the included studies

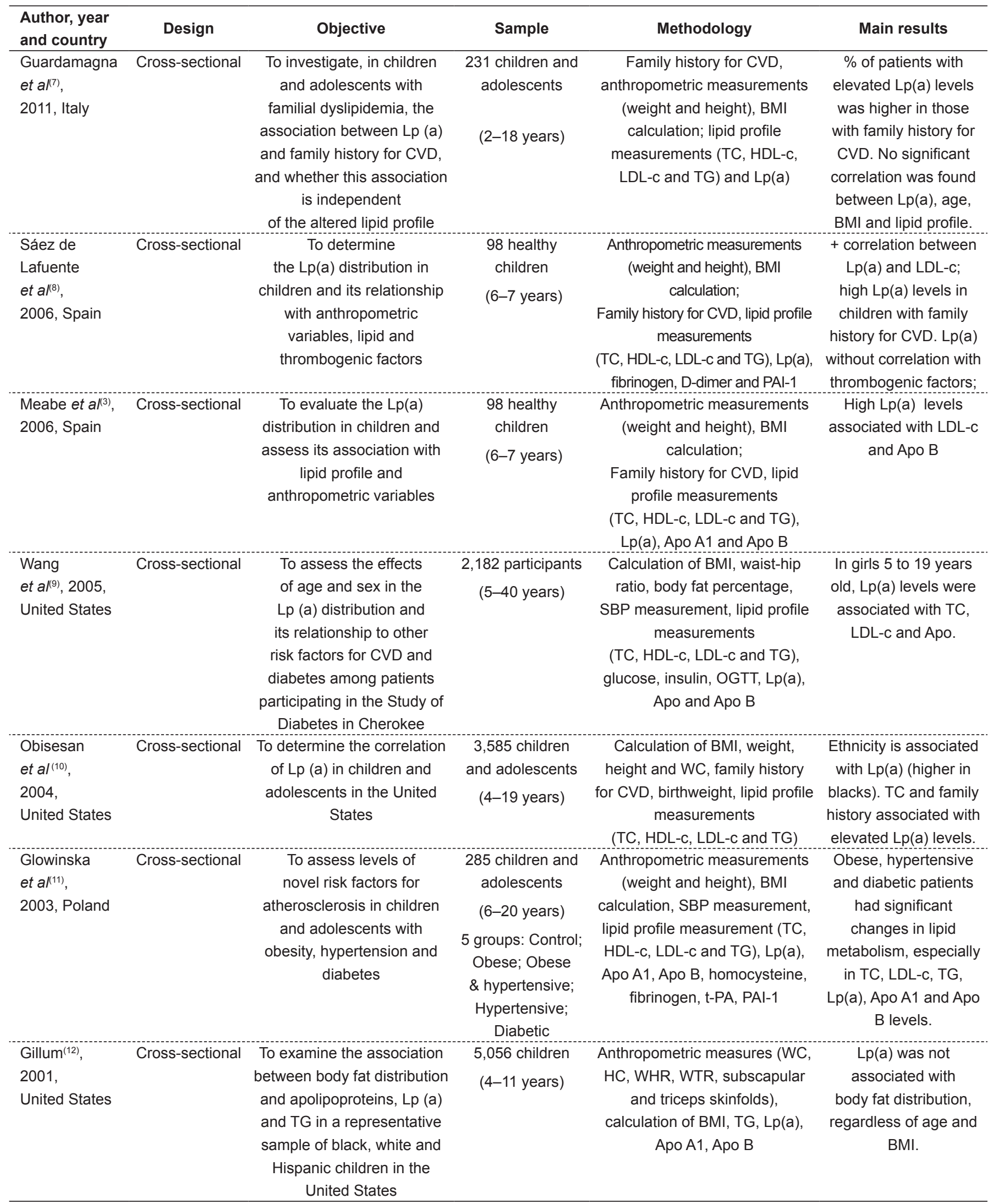

BMI: body mass index; TC: total cholesterol; HDL-C: HDL cholesterol; LDL-C: LDL cholesterol; TG: triglycerides; SBP: systemic blood pressure; Hcy: homocysteine; PAI-1: plasminogen activation inhibition; Apo A1: apolipoprotein A1; Apo B: apolipoprotein B; OGTT: oral glucose tolerance test; t-PA: tissue plasminogen activator; WC: waist circumference; HC: hip circumference; WHR: waist-hip ratio; WTR: waist-thigh ratio 
The data were independently extracted by three authors, and disagreements were consensually resolved. The selected articles were classified according to year of publication, survey location, study type, population's characteristics (subjects, number and age group), objectives, methodology and major findings.

\section{Results}

Initially, 672 papers were screened in the mentioned databases, but 667 were excluded (257 were revisions, 195 were not related to the topic, 140 were books and book indexes, 52 were not available in the full online version, 12 were only references, ten were mostly focused on other outcomes and one was found in two different databases). Thus, only five met the established inclusion criteria for this review. After reviewing the references of the selected articles, two new ones were added, totaling seven articles described in Table 1.

Regarding the population, four studies included children and adolescents, and only one included also adults. All investigations were conducted with boys and girls, aged from two to 19 years old.

The studies were conducted with healthy, dyslipidemic, obese, hypertensive or diabetic children and adolescents. The sample of most studies was obtained from other ones performed with larger numbers of participants.

All the selected papers were cross-sectional and carried out in Italy, Spain, United States and Poland. None of them was conducted in Brazil. Of the three studies carried out in the United States, two worked with different ethnic groups (white, black and Hispanic).

Some of the investigations assessed the family history for CVD. In all of them, $\mathrm{Lp}$ (a) levels were increased in patients with family history for the diseases. The $\mathrm{Lp}$ (a) dosage was performed with the patient's serum using two different techniques (immunoturbidimetry and ELISA). For the Lp(a) levels interpretation, most studies considered the values above $30 \mathrm{mg} / \mathrm{dL}$ as high, as recommended in the III Brazilian Guidelines on Dyslipidemias and Guideline of Atherosclerosis Prevention - Atherosclerosis Department of the Brazilian Society of Cardiology ${ }^{(13)}$.

The goal of most studies was to investigate the relationship between $\mathrm{Lp}(\mathrm{a})$ and other cardiovascular risk factors, mainly the lipid profile, as well as anthropometric measurements and thrombogenic factors.

\section{Discussion}

The fundamental aim of this systematic review was to evaluate whether $\mathrm{LP}(\mathrm{a})$ is associated with other cardiovascular risk factors. Although the action mechanisms associated with $\mathrm{Lp}(\mathrm{a})$ are still unclear, its involvement in atherosclerotic processes is active and silent ${ }^{(5)}$. Recent studies have reported that $\mathrm{Lp}(\mathrm{a})$ is a stable risk marker of the vascular diseases major forms, with atherogenic and thrombotic properties ${ }^{(6)}$.

$\mathrm{Lp}$ (a) shows a double-atherogenic character due to the fact that its lipid composition is similar to LDL and to the presence of apolipoprotein (a) in its structure, a protein with high degree of homology with plasminogen ${ }^{(14)}$. In the study by Guardamagna et al $l^{(7)}$, patients with family history of three or more cardiovascular events were more likely to have high Lp(a) levels, regardless of other lipid fractions. This fact could be observed in two other studies, Sáez de Lafuente $e t a l^{(8)}$ and Obisesan $e t a l^{(10)}$, in which the family history was significantly associated with elevated $\mathrm{Lp}$ (a) levels. These results indicate the need for pediatricians and cardiologists' attention in order to identify and early intervene in the risk factors in children and adolescents with proven family history for CVD.

Family history is a strong and independent risk factor for CVD. At genetic level, a gene involved in the risk of developing a certain disease may predispose individuals of the following generations to the same risk ${ }^{(6)}$. Positive family history for several cardiovascular events or stroke can be a simple criterion to assess pediatric patients who could benefit from $\mathrm{Lp}(\mathrm{a})$ measurements, thus contributing to identify patients at higher risk for $\mathrm{CVD}^{(7)}$.

A positive correlation was observed between $\mathrm{Lp}(\mathrm{a})$ and LDL cholesterol (LDL-c) $)^{(3,8,9)}, \mathrm{Lp}(\mathrm{a})$ and total cholesterol (TC) ${ }^{(9,10)}$ and $\mathrm{Lp}(\mathrm{a})$ and apolipoprotein B (Apo B $)^{(3,9)}$, which suggests an association between $\mathrm{Lp}(\mathrm{a})$ levels and lipid profile. According to Meabe et al(3), the fact that high Lp(a) levels are associated with high LDL-c levels proposes that the LDL metabolism may be involved in the Lp(a) synthesis. In patients with high LDL-c levels, $\mathrm{Lp}(\mathrm{a})$ is an important factor to determine atherosclerotic disease, as well as its severity and progression rate $\mathrm{e}^{(15)}$.

According to Giuliano et $a l^{(16)}$, serum lipids and lipoproteins levels undergo profound changes during growth and development, with two phases of significant increase: up to the second year of life and during sexual maturation. There 
is also a significant increase in LDL-c in puberty, especially among white boys.

In the study by Wang et a ${ }^{(9)}$, girls showed Lp(a) levels associated with TC, LDL-c and Apo B. Epidemiological studies on the lipid distribution in children and adolescents have shown high levels of all lipoproteins and lipids in girls, regardless of age or skin color ${ }^{(16)}$. The general consensus in literature confirms that $\mathrm{Lp}$ (a) concentrations are largely genetically determined ${ }^{(9)}$, being therefore considerably variable between populations ${ }^{(17)}$.

In the study by Obisesan $e$ a $l^{(10)}$, high $\mathrm{Lp}$ (a) levels were observed in black individuals. They have higher levels compared to other populations and the distribution is less distorted than in white individuals. Moreover, Lp(a) provides less risk in blacks than in whites, Asians or Indians. This risk is reduced due to its lower anti-atherogenic lipid profile (low LDL-c and triglycerides and high HDL-c levels compared to whites), which can partly offset the atherogenic potential of $\mathrm{Lp}(\mathrm{a})^{(15)}$.

In the study by Glowinska et $a l^{(11)}$, young obese, hypertensive and diabetic patients showed significant changes in lipid metabolism, particularly in relation to TC, LDL-c, triglycerides (TG), as well as $\mathrm{Lp}(\mathrm{a})$, apolipoprotein $\mathrm{A}$ (Apo A) and Apo B levels. This changed lipid profile was characteristic in children with obesity associated to hypertension. Several studies have demonstrated association between obesity and hypertension in children of various racial and ethnic groups, regardless of gender and age, synergistically influencing the cardiovascular risk. There are higher levels of blood pressure and/or higher prevalence of hypertension in obese children and, according to some authors, their risk of developing hypertension is two to three times higher than in non-obese individuals ${ }^{(18)}$.

It has been well documented in literature that there is a direct correlation between plasma TC levels and LDL-c with CVD. Moreover, there is an inverse correlation between plasma HDL cholesterol (HDL-c) levels and the risk for these diseases. However, unlike the available literature on the CVD risk, the correlation between apolipoprotein abnormalities is not well established in diabetic and hypertensive patients ${ }^{(14)}$.

According to some authors, apolipoprotein A1 (Apo A1) and Apo B concentrations have a stronger correlation with the atheroma development when compared to their equivalent lipoproteins LDL and HDL; in children, they are associated with coronary artery disease in their parents ${ }^{(11)}$. Plasma Apo B concentrations have been considered a better representative of atherogenic particles, and some studies have shown that elevated plasma Apo B levels may be a valuable predictor of coronary artery diseases ${ }^{(14)}$.

According to Sáez de Lafuente et $a^{(8)}$, obesity is another risk factor for CVD, significantly associated with lipids and lipoprotein metabolism. Studies have shown that obese children and adolescents have, even before reaching maturity, risk factors for CVD development, such as dyslipidemia, hyperinsulinemia, increased blood pressure and autonomic dysfunction ${ }^{(19)}$. According to Silva and Zurita ${ }^{(20)}$, childhood obesity is a risk factor for increased morbidity and mortality in adults, causing the later onset of CVD such as hyperlipidemic, colorectal cancer, type 2 diabetes, gout and arthritis. Obese children are also submitted to severe psychological stress due to social stigma. There are also frequent respiratory, orthopedic, dermatologic and immunologic complications, as well as hormonal disorders.

Pinhas-Hamiel $e t$ al ${ }^{(21)}$ reported that, in normal weight children, serum $\mathrm{Lp}$ (a) levels remain relatively constant throughout puberty. Glowinska et $a l^{(11)}$ found that $\mathrm{Lp}(\mathrm{a})$ levels are higher in diabetic patients, a fact that can be ambiguous in literature, because some studies claim that higher $\mathrm{Lp}(\mathrm{a})$ concentration is present in all diabetic children and others have reported increased $\mathrm{Lp}$ (a) concentrations only in patients with inadequate metabolic control. That is, further studies should be carried out in order to obtain a better understanding about the involvement of this marker in relation to diabetes. Nawawi et al ${ }^{(22)}$ reported that it is well established that diabetic patients have an increased risk of developing atherosclerotic vascular diseases compared with non-diabetic subjects. However, the contribution of $\mathrm{Lp}(\mathrm{a})$ in atherosclerotic complications in patients with type 1 and type 2 diabetes is still unclear. There are conflicting results as to whether $\mathrm{Lp}(\mathrm{a})$ concentrations are elevated in type 1 and type 2 diabetes. Several studies have shown that high $\mathrm{Lp}$ (a) concentrations in type 2 diabetes patients are an independent risk factor for coronary diseases, but, in relation to type 1 diabetes, the results are conflicting $^{(22)}$.

In the study by Sharma $e t a l^{(23)}$, conducted with obese or overweight African-American children and adolescents, it was found that $\mathrm{Lp}(\mathrm{a})$ is not considered an independent risk factor for CVD. There are some possible reasons for the controversial results found by studies on $\mathrm{Lp}(\mathrm{a})$ and cardiovascular risk factors. The factors affecting the plasma levels of this lipoprotein are different in each population. Dietary habits, 
genetic factors, lifestyle and race are important factors that affect diseases of multifactorial origin, such as CVD.

In this context, some limitations of the present review should be noted. A small number of scientific studies met the established inclusion criteria. Despite attempts to search the references of the selected articles, only two additional studies were found. Moreover, the number of studies excluded from the review, mainly after the first screening, reflects the literature on this subject. Several studies were actually focused on the association between $\mathrm{Lp}$ (a) and cardiovascular risk in children and adolescents. It is noteworthy that all studies showed cross-sectional design. Additionally, long-term studies on cardiovascular risk factors are needed, because there are several metabolic and anthropometric changes in the age group under study, especially during puberty ${ }^{(24)}$.

The association between $\mathrm{Lp}(\mathrm{a})$ and cardiovascular risk factors was studied mainly by international groups. Brazilian research may bring a more reliable and adequate panorama of our population, particularly among children and adolescents, in which $\operatorname{Lp}(\mathrm{a})$ is a possible predictor of CVD risk.

\section{References}

1. Bergmann GG, Gaya A, Halpern R, Bergmann ML, Rech RR, Constanzi CB et al. Body mass index to the cardiovascular disease risk screening in infancy. Arq Bras Endocrinol Metabol 2011;55:114-20.

2. Silva MA, Rivera IR, Ferraz MR, Pinheiro AJ, Alves SW, Moura AA et al. Prevalence of cardiovascular risk factors in child and adolescent students in the city of Maceió. Arq Bras Cardiol 2005;84:387-92.

3. Meabe YS, Bernar ML, Chivite JP, Gofinondo IN, Rius MV, López AM et al. Correlación de los perfiles lipoproteicos y variables antropométricas con concentraciones séricas de lipoproteína(a) en la infancia. An Pediatr (Barc) 2006;64:235-8.

4. Mota AP, Carvalho MG, Lima LM, Santos ME, Sousa MO. Lipoprotein (a) in patients with peripheral arterial obstructive disease and/or type 2 diabetes mellitus. J Bras Patol Med Lab 2008;44:89-95.

5. Mello AP. Lipoproteína de baixa densidade eletronegativa (LDL-) em indivíduos com diferentes níveis de risco cardiovascular: parâmetros nutricionais e bioquímicos [tese de mestrado]. São Paulo (SP): USP; 2007.

6. Rêgo LF. Correlação entre os níveis plasmáticos de Lp(a), ApoA-I e ApoB e a doença coronária [tese de mestrado]. Vila Real (PT): UTAD; 2009.

7. Guardamagna O, Abello F, Anfossi G, Pirro M. Lipoprotein(a) and family history of cardiovascular disease in children with familial dyslipidemias. J Pediatr 2011;159:314-9.

8. Sáez de Lafuente JP, Sáez Y, Vacas M, Lafita M, Narváez I, Santos M et al. Lipoproteína(a), variables antropométricas, parámetros lipídicos y trombogénicos en la infancia. Clin Invest Arterioscl 2006;18:82-8.

9. Wang W, Lee ET, Alaupovic P, Blackett P, Blevins KS. Correlation between lipoprotein(a) and other risk factors for cardiovascular disease and diabetes in cherokee indians: the Cherokee Diabetes study. Ann Epidemiol 2005; $15: 390-7$
According to Silva and Bittar ${ }^{(25)}$, immediate interventions should be performed as soon as the first risk factors for CVD are identified in children and adolescents.

Considering this potential and the fact that there are few investigations about this new risk marker, more studies and researches on this topic should be carried out, which can provide support for intervention programs in health promotion and for actions to prevent and reduce cardiovascular risk factors in childhood and adolescence, providing greater participation of professionals involved in health promotion, and contributing to reduce morbidity and mortality.

However, the implementation of programs to change the lifestyle of risk factors carriers should be associated with environmental changes, which favors individual choices in adopting and keeping healthy habits. Moreover, encouraging cultural appreciation of health is an extremely important tool to achieve the healthy lifestyle goals.

It is expected that all these considerations help in the development of epidemiological research on these new cardiovascular risk markers in Brazil.

10. Obisesan TO, Aliyu MH, Adediran AS, Bond V, Maxwell CJ, Rotimi CN. Correlates of serum lipoprotein $(A)$ in children and adolescents in the United States. The third National Health Nutrition and Examination Survey (NHANES III). Lipids Health Dis 2004;3:1-10.

11. Glowinska B, Urban M, Koput A, Galar M. New atherosclerosis risk factors in obese, hypertensive and diabetic children and adolescents. Atherosclerosis 2003;167:275-86.

12. Gillum RF. Indices of adipose tissue distribution, apolipoproteins B and AI, lipoprotein (a), and triglyceride concentration in children aged 4-11 years: the Third National Health and Nutrition Examination Survey. J Clin Epidemiol 2001;54:367-75.

13. Autoria não referida. Resumo das III Diretrizes Brasileiras sobre Dislipidemias e Diretriz de Prevenção da Aterosclerose do Departamento de Aterosclerose da Sociedade Brasileira de Cardiologia. Arq Bras Cardiol 2001;77 (Suppl 3):1-48.

14. Lima LM, Carvalho MG, Soares AL, Lasmar MC, Novelli BA, Sousa MO. Apolipoproteins A-I and B plasma levels correlations with lipid profile in subjects with type 2 diabetes mellitus and high blood pressure. J Bras Patol Med Lab 2005;41:411-7.

15. Enas AE, Chacko V, Senthilkumar A, Puthumana N, Mohan V. Elevated lipoprotein(a) - a genetic risk factor for premature vascular disease in people with and without standard risk factors: a review. Dis Mon 2006;52:5-50.

16. Giuliano IC, Coutinho MS, Freitas SF, Pires MM, Zunino JN, Ribeiro RQ. Serum lipids in school kids and adolescentes from Florianópolis, SC, Brazil. Arq Bras Cardiol 2005;85:85-91.

17. Lima LM, Carvalho MG, Sabino AP, Sousa MO. Lipoprotein(a) and fibrinolysis inhibition in coronary artery disease. Rev Bras Hematol Hemoter 2006;28:53-9.

18. Cordinhã AC, Paúl A, Fernandes L. Childhood obesity and arterial hypertension a reality in preschool-aged children. Acta Pediatr Port 2009;40:145-9. 
19. Miranda JM, Ornelas EM, Wichi RB. Childhood obesity and cardiovascular risk factors. ConScientiae Saude (Impr) 2011;10:175-80.

20. Silva VP, Zurita RC. Prevalência dos fatores de risco da obesidade infantil nos centros municipais de educação infantil do município de Maringá-PR 2010. Rev Saude Pesq 2012;5:9-25.

21. Pinhas-Hamiel O, Lerner-Geva L, Copperman NM, Jacobson MS. Lipid and insulin levels in obese children: changes with age and puberty. Obesity (Silver Spring) 2007;15:2825-31.

22. Nawawi HM, Muhajir M, Kian YC, Mohamud WN, Yusoff K, Khalid BA. Type of diabetes and waist-hip ratio are important determinants of serum lipoprotein (a) levels in diabetic patients. Diabetes Res Clin Pract 2002;56:221-7.

23. Sharma S, Merchant J, Fleming SE. Lp(a)-cholesterol is associated with HDL-cholesterol in overweight and obese African American children and is not an independent risk factor for CVD. Cardiovasc Diabetol 2012;11:1-7.

24. Tavares LF, Yokoo EM, Rosa ML, Fonseca SC. Metabolic syndrome in Brazilian children and adolescents: systematic review. Cad Saude Colet 2010;18:469-76.

25. Silva CP, Bittar CM. Fatores ambientais e psicológicos que influenciam na obesidade infantil. Rev Saude Pesq 2012;5:197-207. 